\title{
TEACHING LANGUAGE AND CULTURE WITH THE CONSIDERATION OF ETHNO-PSYCHOLOGICAL ASPECTS OF COMMUNICATION
}

\author{
Tatiana Pochinok ${ }^{1}$, Dana Bartosh ${ }^{2}$, Elena Stoyanova ${ }^{3}$
}

\begin{abstract}
The authors support the idea that in teaching language and culture it is necessary to consider the ethno-psychological aspects of communication which are revealed through the different values, perceptions and norms of the communicative behavior of the speakers.

What the authors have in mind by the ethno-psychological aspects of communication are the ethno-psychological peculiarities of the speakers that belong to different cultures. They are connected with their mentality and revealed by it. Ethno-psychological peculiarities can influence the communicative norms and linguistic structures that the speakers use interacting with their foreign partners and thus cause misunderstanding in international communication.
\end{abstract}

That is why in the process of teaching language and culture the perception of a target culture in comparison with the perception of a native culture should be taken into consideration. The knowledge of the ethno-psychological peculiarities can be provided through culture-related texts called Value and Language Capsules.

Value Capsules present the information about the views and perceptions of a target culture in comparison with a native culture. Assignments connected with the Value Capsule teach the students to identify, analyze and compare the ethno-psychological peculiarities. Language Capsules, on the other hand, are focused on the communicative norms and linguistic structures to realize the ethno-psychological peculiarities of a representative of a target culture. The assignments connected with Language Capsules are directed to predict and plan the possible communicative behavior of international partners in certain intercultural situations.

Key words: intercultural communication, culture, mentality, ethno-phychological peculiarities, cultural texts.

1. Associate Professor, $\mathrm{PhD}$ (candidate of pedagogical sciences) at Fransick Scorina Gomel State University, Belarus, e-mail: pochinok@list.ru

2. Professor, Doctor of pedagogical sciences at Moscow State Linguistic University Moscow, Russia, e-mail: d.bartosh@linguanet.ru, SCOPUS ID: 57205527956

3. Professor, PhD at Shumen University, Department of Russian Studies, Shumen, Bulgaria, e-mail: elvikstoyanova@shu.bg, Web of Science Researcher ID: C-5560-2017 


\section{Introduction}

In the modern world, the dialogue between cultures becomes the fundamental philosophy of life and a form of coexistence. The concept of intercultural dialogue appeared in scientific research at the beginning of the twentieth century in the works of K. Jaspers, O. Spengler, M. Buber, M. Bakhtin and is established in modern science as the interaction, influence, penetration or rejection of cultures. Intercultural communication seems to be a factor in the formation of the dialogue of cultures and the result of its implementation. So, through intercultural communication diverse forms of relations and communication between individuals and groups belonging to different cultures are revealed.

In the applied aspect, intercultural communication is defined as an adequate understanding of two participants in a communicative act belonging to different national cultures (Vereshchagin \& Kostomarov, 1990, p. 26). In order to achieve such an understanding, one should form intercultural competence as an important component of the communicative competence in a foreign language.

\section{Previous research in the field}

Edward Hall (1987), one of the founders of intercultural communication, considered culture as communication. The works of Edward Hall became the impetus for the development of theories of intercultural communication in the 1950-60s.

Intercultural communication can be defined as an interpersonal communication, which has additional characteristics - similarities and differences in languages, non-verbal means of communication, ways of perception, values and ways of thinking (Prohorov, 1996, p. 104). This definition indicates all the main components that, on the one hand, relate to the phenomena of the nationalcultural specificity of verbal communication, and on the other hand, are related to the correlation of levels of "inter-cultural interaction".

The role and place of "cultural sphere" (after Lihachev, 1994) in ensuring communication in target language and clarification of national-cultural features of speech communication is of particular interest in the process of learning a foreign language. "The peculiarity of each language system consists precisely of the peculiarities of the combinations of meanings and linguistic units, resulting one way or another in a common semantic picture of the world" (Kolshanskiy, 1990, p. 61). Further on the same author states that "The so-called linguistic picture of the world is not actually linguistic, it is an expression of cognitive activity due to history, geography, culture and other factors within the framework of a common objective world (but not linguistic)" (Kolshanskiy, 1990, p. 31). 
Culture instills in the individual certain patterns of thinking, perception and behavior that are generally accepted among the members of the community to which he/she belongs. Individual cultural models affect the way we think, move, express ourselves verbally and non-verbally (see Kim, 1988).

The cultural model (from lat. modulus - "measure", "sample") is a holistic image of the world, which is formed within the framework of the initial worldviews of a social community. A certain level of "isolation" of the person from the natural environment corresponds to their own forms of experiencing the world, which are fixed by the corresponding model of the world (Ten, 2007, p. 9-10).

The most important components of the cultural model of the world are space, time, reason, fate, the relationship of the part and the whole, sensual and transcendent, etc. Together, these concepts form a kind of a "net of coordinates", through which the bearers of a certain culture perceive and realize the world, thereby create its image. Cultural models are implemented in various semiotic incarnations, coordinated by themselves into a single universal sign-symbolic system of this culture. The cultural model of the world is specific and varies among different peoples.

Belonging to a certain culture is determined by the presence of a basic stereotypical core of knowledge. It is repeated in the process of socialization of an individual in a given society and is fairly stereotyped. The national role is formed during the first stages of socialization and it is common to all representatives of this culture. Cultural knowledge is acquired as part of entering this role, which determines the national specificity of a person. This knowledge can be considered as a "cultural foundation" of a representative of a certain culture. It can be understood as "a certain set of knowledge, a certain outlook in the field of national and world culture, information about the past of the people, etc., possessed by an 'average' (typical) representative of one or another linguocultural community. It is not a question of possession of this knowledge by an average, typical representative of a given culture, but of the availability of this knowledge in the cultural fund" (Prohorov, 1996, p. 14).

The reality of mastering a new culture is due to the fact that the individual originality of ethnic cultures lies in special systematic combinations of the elements of experience that can be repeated in many cultures (Pochinok, 2012). A representative of a different ethnic community recognizes the "familiar" elements in the new one based on his/ her own stereotypes. However, in the new system these elements are organized according to the combinations of different stereotypes, and therefore the "alien" is distinguished. It is a different combination of well-known elements, and not actually new elements. On the one hand, it can be the cause of problems of intercultural communication, and on the other hand, it is the reason for the stereotypes of perception of a foreign culture being fixed in the minds of the representatives of a certain 
culture (Prohorov, 1996, p. 18).Communicating with each other and using their own language code, customs, traditions, attitudes and norms of behavior, they try to understand and take into consideration a different linguistic code, other customs, traditions, attitudes, everyday ways of communication that are perceived or defined by them as "alien". In this sense, intercultural are all those human relationships in which a given cultural system can be discovered when it goes beyond its boundaries (Bartosh, 2018, p. 14). Undoubtedly, the necessary element in ensuring intercultural communication is taking into consideration both of "one's own" perception of the elements of native culture, and their "other" perception, which must be included in the process of teaching language and culture (Prohorov, 1996, p. 24).

\section{Data Analysis}

Verbal communication in the language being studied is considered within the framework of ethno-psycholinguistics - "a special field of knowledge, the subject of which is the processes of communication in their national-cultural aspect, i.e. structure and characteristics of ethnocultural features that determine the national identity of verbal communication" (Leontev, 1977, p. 5-14).

Difficulties in the ethno-phychological field are associated with the characteristics of ethnic values and stereotypes manifested in communication. These can cause sociocultural errors as the result of differences in the sociocultural perception of the world (Safonova, 1996, p. 105-106). As a rule, communication difficulties caused by the sociocultural characteristics of its subjects are accepted by the participants as a matter of fact. Each communication partner as a representative of a certain culture, as a person whose thinking, as L.V. Shcherba mentioned, is "cast" in the form of a native language, interacts with other people in accordance with the norms, traditions, way of thinking and attitude referred to in his own culture (Baklashkina, 2003, p. 54-55).

The ethnologist G. G. Skvortsov believes that the basis of ethnicity is the psychological basis. Ethnic identity gives rise to a sense of belonging to a community, the members of which can vary in a variety of ways, but at the same time feel their unity for the reason that they are all of "one nationality" (Skvortsov, 1995, p. 11).

Intercultural dialogue is based on a deep dialectic of differences of partners, which can differ from each other in value orientations, way of life and lifestyle, patterns of speech behavior. However, through comparing with another culture in the process of dialogue of cultures, self-assertion and cultural awareness are carried out. In the process of intercultural dialogue, a new act of communication is developed for the participants in the communication of the meaning of the actions performed and perceived and their motives based on the unity of 
the participants. According to L.M. Batkin, a feature of dialogue, including intercultural dialogue, is "a clash of different minds, different truths, dissimilar cultural positions that make up a common mind, a common truth and a common culture" (cit. Kagan, 1988, p. 152).

At the same time being a participant of the intercultural dialogue it is very important to keep and value your cultural identity which gives the opportunity to become a participant of a global world staying culturally unique (Bartosh, 2018, p. 19).

The similarity of the traits of national psychology, according to N. Dzhandildin, is an indisputable fact, since without it the national community would be reduced to the sum of external, unifying attributes, and the nation itself would remain internally fragmented in the sense of ethno-psychological disunity (Dzhandildin, 1971, p. 27). This gives us the reason to believe that representatives of different ethnic communities are characterized by ethno-psychological features, which determine the ethnocultural peculiarities of the representative of linguistic culture to the surrounding reality (Kytina, Pochinok \& Bartosh, 2020, p. 182).

Using the criteria and through the analyses, it is possible to define ethnopsychological peculiarities of the representative of any culture. The analyses of ethno-psychological peculiarities can be carried out on the basis of scientific and methodological works, audio-visual means, works of authentic fiction. These are the criterion of value contrast and the criterion of the specific manifestation of ethno-psychological peculiarities in the behavior.

The criterion of value contrast suggests the allocation of ethnospecific relations of speakers of a foreign language culture to him/herself, to other representatives, to the surrounding reality, which are caused by different value orientations in comparison with native speakers of linguistic culture. Different value orientations of the speakers of linguistic cultures determine the nationalcultural specificity of the views, assessments, relationships, beliefs that are manifested in the national-cultural specificity of verbal behavior.

We define the criterion of the specific manifestation of ethno-psychological peculiarities in the behavior as an ethnospecific attitude of the speakers of a foreign culture to themselves and to other representatives, to the surrounding reality, which are realized in ethnospecific norms of behavior that are different from the norms of behavior of the speakers of a native culture (Pochinok, 2012, p. 22).

According to these criteria while teaching language and culture the information of certain ethno-psychological peculiarities can be presented to the students through cultural texts. These texts provide information about the native speaker of a target language: the ways of its activities, the system of value orientations and attitudes, the norms of speech behavior, behavioral strategies, the speech means 
of writing statements. The cultural text, as well as any text, reflects the unity of the external (linguistic) and internal (extralinguistic) aspects of communication. The external side is the linguistic means and ways of expressing thoughts, and the internal side is associated with the information about the culture of the participants in intercultural interaction. In the process of perceiving the linguistic form of the text, the student comprehends its content on the basis of the analysis of cultural information, comparing it with his/ her experience of perceiving him/herself and the surrounding reality, and, as a result, there is an understanding of how culture determines the way of thinking and the behavior of the speaker of the target language.

Cultural texts are not only a source of information about the ethno-psychological peculiarities of a representative of a different linguistic and cultural community, but also a tool for influencing the perception of students, as well as a means for their socio-cultural development. In the process of working with a cultural text, students consistently form stable ideas and perceptions about the representative of the language being studied, their value orientations and attitudes, behavioral strategies. While studying these texts sociocultural abilities and sociocultural qualities are brought up. After acquiring this knowledge through the cultural texts the students can be trained with a set of assignments to realize the intercultural communication taking into consideration the ethno-psychological peculiarities of a foreign speaker (Kytina, Pochinok \& Bartosh, 2020, p. 177-181).

Thus, the result of work on culturally rich texts is not only new knowledge and methods of activity, but also a new level of the students' development.

Cultural texts can be called "Value Capsule" (term "Culture Capsule" by H. Taylor and D. Sorens) and "Language Capsule". "Value capsules" and "Language capsules" are cultural texts about the foreign language and culture being studied (Pochinok, 2012, p. 70-72). In the "capsules", the ethno-psychological peculiarities of the speakers of the target language are updated by the examples of their attitude to themselves and their personal space, to other representatives, to the surrounding reality, as well as to national value orientations, norms of foreign-language communicative behavior and linguistic tools for writing speech expressions. Specially selected cultural information is packed/stored in "capsules" under a certain topic and acts as a basis for understanding the ethno-psychological peculiarities of the speakers of the target culture. "Value capsules" get the titles in accordance with the national-specific value orientations of native speakers of a foreign culture, which contrast with the value orientations of native speakers. In "Language capsules", the headings reflect the communicative functions in the context of which the linguistic means presented in the "language capsule" are used. The most important criteria for selecting linguistic tools for "Language capsules" is their authenticity and frequency in real communication of native speakers of the studied language. 
The "Value Capsule" focuses students on the perception and understanding of the reality and national value orientations of the representatives of the studied linguistic culture in comparison with the representatives of their native culture. The "Value capsules" show how value orientations determine the attitude of the speakers of the studied language to themselves, to other people/speakers/ cultures and to the surrounding reality. The work of students on "Value capsules" involves the analysis, comprehension and generalization of cultural material using specially designed assignments. "Value capsules" help students understand how the ethno-psychological peculiarities of native speakers of the language being studied are reflected in communicative behavior and define it.

The "Language Capsule" is thematically connected with the "Value Capsule". The "Language capsule" contains information on how the value orientations of the speakers of the studied language described in the "Value capsule" are realized in the strategies of communicative behavior. "Language Capsules" present the norms of communicative behavior, as well as linguistic tools to be used in the intercultural situations with a native speaker of a foreign culture.

We can suggest a set of thematically connected Value and Language Capsules that can be used for acquiring sociocultural knowledge about the representatives of American culture (Pochinok, 2012, p. 152). The topics of Value Capsules are defined according to the key ethno-psychological peculiarities of the representatives of American culture: polite friendliness, preservation of personal space and positive perception (Pochinok, 2012, p. 30). So, the sociocultural knowledge about the polite friendliness of Americans can be acquired through the Value Capsule "Friendliness versus Friendship", Value Capsule "Individual freedom and self-reliance of Americans" can present the information about the preservation of personal space and students can study the information about positive perception of Americans in the Value Capsules "The power of positive thinking", "The American perception of "success" and "Self-presentation on the job-interview". Language Capsules include the information about the communicative norms and linguistic structures by which this peculiarity is revealed in the intercultural communication.

Value Capsule

"Friendliness versus

Friendship"
Language Capsules:

1. "Initiating small talk in America";

2. "Keeping the conversation ball going"

3. "Dealing with personal questions"

4. "Avoiding silence in American conversation"

5. "Changing the subject in the talk"

6. "Let's not chat".

7. "Sounding clear without words". 


\section{Value Capsule \\ "Individual freedom \\ and self-reliance of \\ Americans"}

Value Capsule "The power of positive thinking"

Value Capsule "The American perception of "success"

Value Capsule "Selfpresentation on the jobinterview"
Language Capsules:

1. "Making a request"

2. "Reacting to a request"

3. "Giving advice".

Language Capsules:

1. "Paying a compliment"

2. "Expressing sympathy".

Language Capsules:

1. "Ways of expressing opinions"

2. "If I hesitate".

Language Capsule "How to answer a tricky question".

Let us make some examples of assignments to work with Value and Language Capsules. So, to acquire the sociocultural knowledge about the ethnopsychological peculiarity "polite friendliness" the students can study the Value capsule 'Friendliness versus Friendship'. In this Value capsule they should find the information about such notions as 'a friend', 'friendship', 'friendliness', 'privacy in friendship'. Additional assignments to this Value capsule teach to identify, analyze and compare ethno-psychological peculiarities of the representatives of a target culture and a native culture (Pochinok, 2012, p. 177-183):

- Answer the questions to the Value Capsule 'Friendliness versus Friendship'

- Say if the statements from the Value Capsule are true of the people of your country. Prove your opinion with some examples.

- Here are different meanings of the word 'friend'. Choose the meaning of the word 'friend' which is close to you. Explain your choice.

- Here is a questionnaire about your attitude to friendship. Answer the questions.

- $\quad$ Study the situation connected with the topic. Choose the answer you think best explains what is going on in the situation. Explain your choice.

- Study the situation happened with two friends. Identify the reason for misunderstanding between them.

The assignments to work with the Language capsule are directed to predict and plan the possible communicative behavior of international partners in certain intercultural situations. We can give some examples of the assignments to work with the Language Capsule "Dealing with personal questions" (Pochinok, 2012, p. 195-199): 
- Study the Language Capsule "Dealing with personal questions". Pay attention to the questions you should avoid in conversations and to the tips how to deal with them. Give the examples of the questions which are considered impolite in your country.

- Choose in the Language Capsule the tip(s) you find the most useful in dealing with personal questions. Did you use it (them)? If yes, how did it (they) work?

- Study the dialogue. Find the questions which are considered personal according to the Language Capsule. Pay attention to the way the speaker dealt with them. Do you consider these questions personal?

- Watch the episode from the film "Up to the sky". Notice the question which was asked and the way the speaker dealt with the question. Come back to the Language Capsule again and say which tip the speaker used. What was the reaction of his partner? Was he offended by such an answer? Why?

- Imagine that someone asked you a personal question. What would you feel? Would you be hurt? Would you feel embarrassed? What are the most embarrassing questions for you? How would you react to them?

- Match the reactions on the left to the personal questions on the right.

Thus, cultural texts can provide the necessary knowledge of the ethnopsychological peculiarities of the representative of a foreign culture to realize the intercultural communication effectively. To understand the communicative behavior of the native speaker of the studied language, it is necessary for students to develop the skills to identify, analyze, evaluate the ethno-psychological peculiarities of the native speaker of the studied language and compare them with the peculiarities of the representative of a native culture. These skills contribute to the development of sociocultural skills and abilities necessary for the effective intercultural communication.

\section{Conclusion}

The key result of the study is that while teaching a foreign language and culture it is necessary to take into consideration the ethno-psychological aspects of communication under which the authors also mean the ethno-psychological peculiarities of a representative of a foreign culture which are connected with his/her mentality and revealed in the forms of national values, views, perceptions and the norms of communicative behavior. The knowledge of ethnological peculiarities can be acquired through cultural texts which are defined as Value and Language Capsules. Cultural Capsules and a set of assignments followed them can teach the students to identify, analyze and compare the ethno- 
psychological peculiarities of the representatives of a target culture and a native culture and also they help to acquire the knowledge of the communicative norms and linguistic structures of a foreign partner to realize an effective intercultural communication.

Thus, in the process of intercultural communication, a functionally determined communicative interaction of representatives of different cultures is carried out, characterized by certain ethno-psychological peculiarities. The ethnopsychological peculiarities of the representative of some culture are actualized in his behavior, actions, judgments, reactions, speech style, influencing the choice of appropriate language forms. The implementation of verbal behavior in accordance with the norms of native culture, without taking into consideration the ethno-psychological peculiarities of a foreign language interlocutor, can lead to the fact that the behavior of the participants in intercultural communication will reflect their own cultural norms that are different from the norms of foreign communicative behavior of the native speaker of the studied language. That is why the ethnic peculiarities should be considered in the process of teaching intercultural communication. They should be acquired through cultural texts and a set of assignments based on them.

\section{References:}

Baklashkina, M. V. (2003). Kulturovedcheskie aspektyi obucheniya studentov 1-2 kursov normam mezhlichnostnogo obscheniya v inoyazyichnoy uchebnoy srede: diss. ... kand. ped. nauk: 13.00.02. Moskva.

Bartosh, D. K., Galskova, N. D., Koptelov, A. V., \& Kharlamova, M. V. (2018). Tekhnologii elektronnogo obucheniya inostrannym yazykam: sostoyanie i perspektivy. Moscow: Moscow state pedagogical University.

Bromley, Yu. V. (1991). Etnicheskie funktsii kulturyi i etnografiya. AN SSSR, In-t etnologii i antropologii im. N.N. Mikluho-Maklaya. Moskva: Nauka, pp. 5-23.

Dzhandildin, N. (1971). Priroda natsionalnoy psihologii. Alma-Ata: Kazahstan.

Hall, E. T. (1987). Hidden differences: Studies in international communication. Tokyo: Bungel shunju.

Hall, E. T., \& Trager, G. L. (1953). The analysis of culture. Washington, DC: Foreign Service Institute, American Council of Learned Societies.

Gershunskiy, B. S. (1999). Rossiya i SShA na poroge tretego tyisyacheletiya = Russia and the USA at the threshold of the third millennium: opyit ekspert. issled. ros. i amer. mentalitetov. Moskva: Flinta. 
Gumilyov, L. N. (2002). Etnogenez i biosfera Zemli. Pb.: Azbuka - klassika.

Golovlyova, E. L. (2008). Osnovyi mezhkulturnoy kommunikatsii. Rostov n/D: Feniks.

Kagan, M. S. (1988). Mir obscheniya: problema mezhsub'ektivnyih otnosheniy. Moskva: Politizdat.

Kim, Y.Y. (1988). Communication and cross-cultural adaptation: an integrative theory. Clevedon.

Kirienko, V. V. (2007). Mentalitet sovremennyih belorusov (sotsiologicheskiy analiz): avtoref. dis. d-ra sotsiolog. nauk: 22.00.06. In-t sotsiologii Nats. akad. nauk Belarusi. Minsk.

Kolshanskiy, G. V. (1990). Ob’ektivnaya kartina mira v poznanii i yazyike. Moskva.

Kornilov, O. A. (2000). Yazyikovyie kartinyi mira kak otrazhenie natsionalnyih mentalitetov: dis. d-ra kulturol. nauk: 22.00.04. Moskva.

Kornilov, O. A. (2007). Dominantyi natsionalnoy mentalnosti v zerkale frazeologii. Vestnik MGU. Lingvistika i mezhkulturn. kommunikatsiya, 19(2), 53-66.

Kytina, V., Pochinok, T., \& Bartosh, D. (2020). Ethnopsychological aspects of intercultural communication and their consideration in the process of teaching students of a Linguistic University. International Journal of Advanced Science and Technology, 29 (6), 175-185.

Leontev, A. A. (1977). Natsionalnyie osobennosti kommunikatsii kak mezhdistsiplinarnaya problema. Ob'em,zadachiimetodyietnopsiholingvistiki - Natsionalno-kulturnaya spetsifika. Moskva, 5-14.

Lihachev, D. S. (1993). Kontseptosfera russkogo yazyika. Moskva: Izvestiya Akademii nauk. Seriya literaturyi i yazyika, 52 (1), 3-9.

Lihachev, D. S. (1994). Kultura kak tselostnaya dinamicheskaya sistema. Vestnik Rossiyskoy Akademii nauk, 94 (8), 721-725.

Markaryan, E. S. (1983). Teoriya kulturyi i sovremennaya nauka. Moskva.

Pavlovskaya, A. V. (1998). Rossiya i Amerika. Problemyi obscheniya kultur. Moskva: MGU.

Pochinok, T. V. (2012). Formirovanie u studentov yazyikovogo vuza sotsiokulturnoy kompetentsii : diss. ... kand. ped. nauk: 13.00.02. Gomel.

Prohorov, Yu. E. (1996). Natsionalnyie sotsiokulturnyie stereotypy i rechevogo obscheniya i ih rol v obuchenii russkomu yazyiku inostrantsev. Moskva: Pedagogika - Press.

Safonova, V. V. (1996). Izuchenie yazyikov mezhdunarodnogo obscheniya $v$ kontekste dialoga kultur i tsivilizatsiy. Voronezh: Istoki. 
Skvortsov, N. G. (1995). Etnichnost i transformatsionnyie protsessyi. Etnichnost. Natsionalnyie dvizheniya. SPb.: Sotsialnaya praktika: Sb. statey.

Ten, Yu. P. (2007). Kulturologiya i mezhdukulturnaya kommunikatsiya. Rostov n/D: Feniks.

Vereshchagin, E. M., \& Kostomarov, V. G. (1990). Language and culture. Moskva: Russian language. 